\title{
A Mobile Remote Lab System to Monitor in Situ Thermal Solar Installations
}

\author{
http://dx.doi.org/10.3991/ijim.v7i1.2292 \\ G. Saez de Arregui ${ }^{1}$, M.Plano², F. Lerro²; L. Petrocelli², S. Marchisio², S. Concari², 3, V. Scotta ${ }^{2}$ \\ ${ }^{1}$ Instituto Nacional de Tecnología Industrial (INTI), Argentina \\ 2 Universidad Nacional de Rosario (UNR), Argentina \\ ${ }^{3}$ Universidad Tecnológica Nacional (UTN)
}

\begin{abstract}
In this paper we describe the design and development of interconnected devices which allow monitoring in situ the performance of solar boilers. This mobile remote lab system comprises two huge blocks of hardware: a mobile station located by the boiler, which is monitored and controlled in a remote way, and a fixed station, located in the Laboratory of Energy for the Sustained Development of the Universidad Nacional de Rosario. The communication between the fixed and mobile devices is controlled by microcontrollers included in both stations and programmed in $\mathrm{C}$ language. The project is being developed through three parallel lines of work: 1) Design and development of fixed and mobile hardware; 2) Development of firmware and software necessary to register and communicate data; 3) Design and development of learning activities. This mobile remote lab will be useful to test the behavior of solar boilers in the place and environmental conditions where they are placed so as to evaluate their performance and efficiency anywhere. This is also in order to contribute for the implementation of norms for the certification of solar boilers. On the other hand, the data and results obtained from the development will be used as supplies for the design of learning activities.
\end{abstract}

Index Terms - remote lab; remote control; mobile technologies; solar boilers.

\section{INTRODUCTION}

The present world consumes fabulous amounts of energy, especially non- renewable.

The growth of society, mainly the western, has been sustained by an energetic matrix based on petroleum and its products, carbon and gas, also by a lack of concern about the exhaustion of natural resources or the ecologic damage produced by their indiscriminate use. Thus, as man has been learning his reality through knowledge and the development of science and technology, environmental problems have increased. On the other hand, with the depletion of non-renewable resources, critical situations that affect production and sustainable development at regional and world level come up.

The transition from a petroleum-based society to another with varied and renewable sources of energy requires at least:

- The development of new technologies and the optimization of the existent ones so as to substitute traditional resources, implement technologies to increase the efficiency of devices, artifacts and equipment.
- The spread of news and the social optimization to lead to the necessary changes in habits and behavior of society so that it is capable to value the energetic resources and to acknowledge the need to control their use.

Assuming the existence of these social needs and trying to provide a significant contribution to people studying engineering and to specialists in the field of renewable energies, the Facultad de Ciencias Exactas, Ingeniería y Agrimensura (FCEIA) of the Universidad Nacional de Rosario (UNR), through its Escuela de Posgrado y Formación Continua offers a Master's Degree in Energy for a Sustainable Development. The aim is to train people with a university degree in the development and implementation of a sustainable energetic development that will try to reduce the environmental impacts of the human activity and to allow a generation of wealth adequate to a sociocultural development.

The career recognizes the important European antecedents in the area, mainly, the Master's Degree in Cataluña bearing the same title; at the same time it tries to develop experimentation related to the devices, equipment and procedures used by the renewable energies. In this context, the Master articulates its activity with the Laboratory for the Sustainable Development of Energy. This Laboratory is an area of unique formation that promotes the creation of new knowledge and technologies in the shape of investigation projects, development and innovation, where both the ones that have a scholarship and the students, get involved and are supervised by specialists and researchers in the area.

With this idea in mind and through the generation of knowledge, technologies and services socially relevant, we try to provide, both the design and implementation of a new energetic model that aims to reduce the environmental impact together with a sustainable development as a relevant issue in the area.

Sometimes the activities of this laboratory require the participation of specialists from other laboratories of the same Postgraduate School. This project in particular is carried out together with two of the laboratories of the Escuela de Posgrado y Formación Continua of the Facultad de Ciencias Exactas, Ingeniería y Agrimensura: the Laboratory of Energy for a Sustainable Energy and the Laboratory of Remote Laboratories.

This other institutional space deals both with the development of technologies for the remote experimentation (through devices at distance), and with didactic materials 
PAPER

A Mobile Remote LAB System to Monitor In Situ Thermal Solar InSTALLATiOnS

that implement those technologies in the development of relevant practical activities.

\section{THE PROBLEM OF MEASUREMENT OF THE REAL EFFICIENCY OF A SOLAR HEATER}

Solar energy occupies an outstanding place among the renewable energies. One of its most developed uses is in the shape of thermal energy to heat drinking water by plane solar collectors with pipes where water circulates. Those pipes are connected to storing tanks setting the base of the so called solar heaters. In Argentina there are several suppliers of solar heaters; however, there is not in the country an organization system that registers the certification and approval of such equipments of thermal solar heating to guarantee a minimum quality. As it is shown [3] after a strong impulse in the 80s, when the norm 210002 IRAM was enforced for tests with plane plate collectors [6], the norm could not be enforced for tests with complete systems. That is why, local manufacturers that are selling their products do not have norms that approve or certify them.

In 2010 el Área Tecnológica Estratégica de Energías Renovables of the Instituto Nacional de Tecnología Industrial (INTI) proposed a system of measurement to supply hot solar water. It pre-supposes a removal to test beds for measurement, test and certification [5]. On this matter, the efficiency of the conversion of a solar heater depends on the following variables: solar radiation, room temperature, inlet water temperature, wind speed, and circulation flow. It is not possible to give an efficient value to the solar collectors, but it is necessary to determine a yield curve that shows the way the solar collector works under different environmental conditions. The yield curve is experimentally determined under controlled conditions of the mentioned parameters and in agreement with the norms. From the survey of the existent norms at national and international level, we chose the European norm UNE - EN 12975 - 2 thermal solar systems and their components - solar collectors - Part 2: Test Method.

It is known that the thermal behavior of equipment is conditioned by its dimensions, materials and technical capacity. The efficiency in the real conversion of a solar heater will also be affected by the weather conditions to which it is exposed. That is why we consider it is necessary to develop a system that allows controlling the behavior of such solar equipments on site. Such a system is described in this work.

Mainly, the development raises the issue to incorporate communication knowledge and technology and remote experimentation to determine the procedures and instructions which, at distance, will allow the determination of the energetic efficiency of solar heaters in the place and environmental conditions where they were set. We consider this will not only bring knowledge and innovations that involve new equipments and procedures, but will also enrich the experimental training of professionals of the subject through the development of authentic practices.

\section{DESCRIPTION}

The system is made up of two huge blocks: a mobile station, placed at the side of the heater that is controlled and monitored remotely, and a fixed station, located at the
Laboratory of Energy for a Sustainable Development, at the UNR. Both stations demand a hardware and software development.

The project is being carried out through three parallel lines of work:

- Design and development of fixed and mobile hardware

- Development of firmware and software needed to register and communicate data

- Design and development of learning activities

\section{A. The Remote Mobile Station}

Figure 1 shows an outline of a remote station. The heater can be seen under test, hydraulically fed by a reserve tank. The heater outlet is connected to an opening and closure valve $(\mathrm{V})$ controlled by the electronic testing system. In both extremes there is a connection that holds a high precision semiconductor junction thermometer (T1 AND T2) that measures the temperature of the inlet and outlet of water. The outlet is connected to a flow meter (C) to measure the amount of water pumped out. Besides, in the collector plane, there is a solar meter ${ }^{\circledR}$ to measure the solar radiation with an incidence and an anemometer (A) to estimate the levels of wind speed.

All this is connected to a remote controlling plate that includes a data logger in charge of the data acquisition and a transmission module of analog and digital data.

The core of the mobile part is a PIC (microchip) microcontroller connected via a Universal Asynchronous Receiver-Transmitter (USART) to a Global System for Mobile Communication (GSM) a computing processing unit with its corresponding line chip. The controlling plate has also a global positioning system that provides additionally data, latitude, length and height above sea level, elements that condition the solar collector performance.

The microcontroller is programmed in C18 language and can:

- Receive the test configuration from the fixed station.

- Get the sensors data (temperature, solar radiation, flow)

- Control the extracting valve

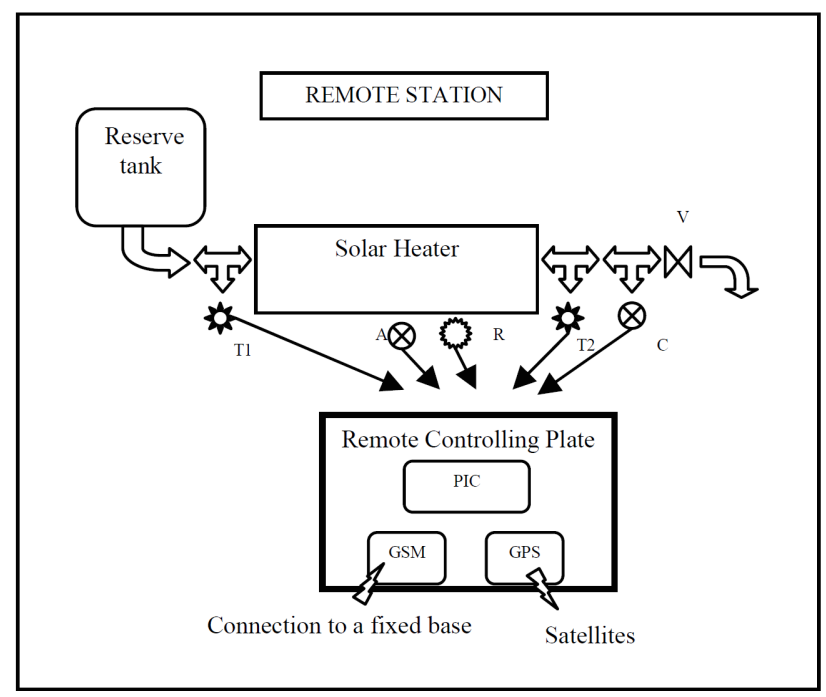

Figure 1. Diagram of a mobile remote station 
PAPER

A Mobile Remote LAB System to Monitor In Situ Thermal Solar InSTALLATiOnS

- Perform an initial processing of data (i.e average temperature and counting volume)

- Assemble the information pack.

- Send data through mobile phones to the fixed station in Rosario, using the SIM900 Module of Simcom that is included in the remote plate and connected to the microcontroller.

Even though at present, the system can use the GSM network in the mobile station with energy supplied by the usual net, the project contemplates a complete feeding by a solar PV system that makes it independent from the electric power network and makes it possible to perform the field measurement anywhere

\section{B. The Fixed Station}

The fixed station integrates with three well differentiated blocks (Figure 2)

- The GSM transmitter-receptor, in charge of communication with the remote station

- The computing processing unit and data base. The former receives and processes the data received from the remote station and stores them in a data base. This system is based on a PC connected to a GSM block via USB.

- The web server connected to the Internet.

The web server:

- Introduces the interface through which the user can ask for the graphs he has to see.

- Communicates with the GSM transmitter-receptor to send information to the remote station.

- Introduces the test results previously processed and stored in the data base to the user. In this way, the owner, importer o developer of the solar heater can see, through the WEB, from any site connected to the Internet o by mobile phones, how his equipment is tested in real time.

\section{Closing UP. From the LAB DEVELOPMENT TO THE ACHIEVEMENT OF LEARNING OBJECTIVES}

The Laboratory of Energy for a Sustainable Development has two solar heaters for didactic uses located in the roof of the Facultad de Ciencias Exactas, Ingeniería y Agrimensura of the Universidad Nacional de Rosario.

One of them has vacuum tube collectors characterized by less thermal losses and better performance compared to those of a plane plate, still it covers a wider surface and is less strong. Regarding this solar heater, we are carrying out the first tests to start the last technical stage of the project, which will deal with the realization of field tests and the contrast of results with the commercial technical specifications. This way, users, installers and companies that produce solar heaters can use the information to optimize the development of equipments. The tests results will be important data that will contribute to the implementation of norms to certify and approve solar heaters.

These tests have been discussed in specific seminars that were coordinated for teachers and students. From the

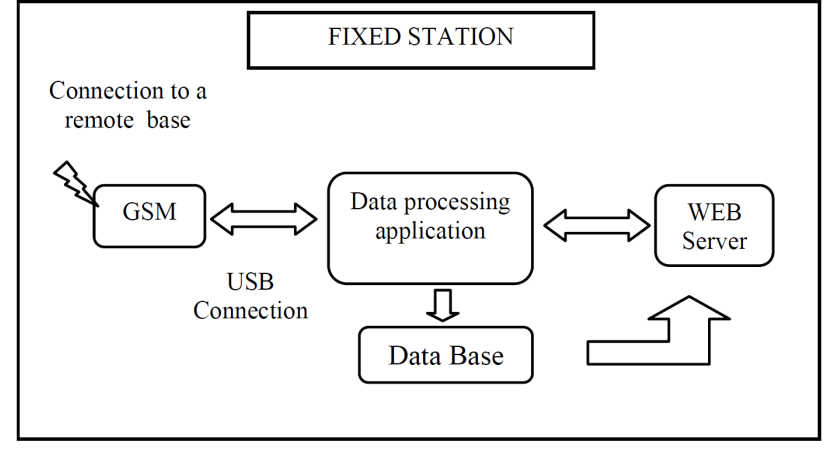

Figure 2. Diagram of the fixed station

point of view of the organizers of the career, this task/design activity, its evaluation and reflection in practice constitute a didactic strategy to give opportunities for setting up an enormously significant learning process. It is the sort of activity that experts of that field meet [4]. Regarding this point, [2] it expresses that the authenticity of the educational practice can be determined by the cultural activities the student shares, as well as through the type and level of the social activities promoted [1].

In this context, we would like to point out the utility and functionality of what has been learnt, its sense and application [2] which promote at the same time the development of abilities and knowledge related to the profession. At the same time it uses and transforms the physical and social environment building up a strong bond between the classroom and the community. Also, the project has been devised to create activities in the shape of experimental work that help to achieve specific learning objectives in the subjects that deal with the study of the exploitation of solar energy with an education for a sustainable development. That is, it is not against the incorporation of the teaching, reading of text books and demonstration; they are used, but in a broader sense and as tools to think over. With this aim, the project team has carried out a survey among authorities and teachers of those subjects so as to be able to devise new learning activities.

\section{REFERENCES}

[1] Derry, S., Levin, J. y Schauble, L “Stimulating statistical thinking through situated simulations” Teaching of Psychology, 22 (1), 1995, pp. 51-57. http://dx.doi.org/10.1207/s15328023top2201_16

[2] Díaz Barriga, F. "Cognición situada y estrategias para el aprendizaje significativo”. Revista Electrónica de Investigación Educativa, 2003. 5 (2). http://redie.ens.uabc.mx/vol5no2/contenidoarceo.html

[3] Garnica, Javier H.; Lucchini, Juan M.; Stoll, Rodolfo G. y Barral, Jorge R. "Ensayos normalizados de colectores solares y sistemas de calentamiento de agua en Argentina: análisis de la situación, avances y dificultades”. Avances en Energías Renovables y Medio Ambiente. $2010 \quad$ Vol. $14 . \quad$ In http://www.cricyt.edu.ar/lahv/asades/averma/2010/ter39.pdf

[4] Hendricks, Ch. "Teaching causal reasoning through cognitive apprenticeship: What are results from situated learning?" The Journal of Educational Research, 94 (5), 2001, pp.302-311. http://dx.doi.org/10.1080/00220670109598766

[5] INTI Energía Solar. El aporte del INTI. 2010. www.inti.gob.ar/erenova/documentos/documentos10.htm

[6] IRAM Norma 210002. Colectores solares. Métodos de ensayo para determinar el rendimiento térmico. Instituto Argentino de Racionalización de Materiales, Buenos Aires, Argentina. 1983. 


\section{AUTHORS}

G. Saez de Arregui is with the Centro Rosario, Instituto Nacional de Tecnología Industrial (INTI), Argentina (e-mail: gsaez@inti.gob.ar).

M. Plano, is with the Facultad de Ciencias Exactas, Ingeniería y Agrimensura - Universidad Nacional de Rosario (UNR), Avda. Pellegrini 250, Rosario, Argentina (e-mail: mplano@fceia.unr.edu.ar).

F. Lerro is with the Facultad de Ciencias Exactas, Ingeniería y Agrimensura - Universidad Nacional de Rosario (UNR), Avda. Pellegrini 250, Rosario, Argentina (e-mail: flerro2@yahoo.com.ar).

L. Petrocelli is with the Facultad de Ciencias Exactas, Ingeniería y Agrimensura - Universidad Nacional de Rosario (UNR), Avda. Pellegrini 250, Rosario, Argentina (e-mail: petrocelli.lucia@gmail.com)

S. Marchisio is with the Facultad de Ciencias Exactas, Ingeniería y Agrimensura - Universidad Nacional de Rosario (UNR), Avda. Pellegrini 250, Rosario, Argentina (e-mail: timbucorreo@gmail.com)
S. Concari is with the Facultad Regional Rosario Universidad Tecnológica Nacional, Zeballos 1341, Rosario, Argentina. She is also with the Facultad de Ciencias Exactas, Ingeniería y Agrimensura - Universidad Nacional de Rosario (UNR), Avda. Pellegrini 250, Rosario, Argentina. (e-mail: sconcari@gmail.com)

V. Scotta is with the Facultad de Ciencias Exactas, Ingeniería y Agrimensura - Universidad Nacional de Rosario (UNR), Avda. Pellegrini 250, Rosario, Argentina. (e-mail: scotta@fceia.unr.edu.ar)

This work was supported in part by the Secretary of Science, Technology and Innovation of Santa Fe State. Project (21-116-10) "Laboratorio remoto móvil de energía solar térmica. Innovación Tecnológica para ensayos/ soluciones conducentes al ahorro energético" ("Mobile Remote Laboratory of solar thermal energy. Technological Innovation for tests / solutions leading to energy savings") and by National University of Rosario. Project 1ING374: "Laboratorio remoto móvil. Integración de dispositivos para la educación en energías renovables" ("Mobile Remote Laboratory. Integration of devices for education in renewable energy") It is an extended and modified version of a paper presented at the International Conference on Remote Engineering \& Virtual Instrumentation (REV2012), held at University of Deusto, Bilbao, Spain, July 4-6, 2012. Received 28 September 2012. Published as resubmitted by the authors 20 December 2012 